\title{
ANALISIS KEMAMPUAN PEMAHAMAN KONSEP MATEMATIS SISWA DALAM MENYELESAIKAN SOAL SPLDV KELAS X
}

\author{
Maria Gratiana Manul ${ }^{1}$, Djoko Adi Susilo ${ }^{2}$, Trija Fayeldi ${ }^{3}$ \\ Program Studi Pendidikan Matematika, Universitas Kanjuruhan Malang ${ }^{1,2,3}$ \\ gratsianamanul@gmail.com ${ }^{1}$, heni.adisusilo@unikama.ac.id ${ }^{2}$, trija fayeldi@unikama.ac.id ${ }^{3}$
}

\begin{abstract}
Abstrak. Fokus penelitian ini bertujuan untuk mengetahui kemampuan pemahaman konsep matematis siswa dalam menyelesaikan soal SPLDV. Pendekatan penelitian ini adalah pendekatan kualitatif yang berjenis deskriptif. Teknik pengumpulan data dilakukan dengan metode tes, wawancara dan dokumentasi. Uji keabsahan data dilakukan dengan teknik triangulasi. Hasil penelitian dari penelitian ini, dari 25 siswa kelas X yang telah mengikuti tes, sebanyak 14 orang mendapatkan nilai dalam kategori tinggi, sebanyak 8 orang memperoleh nilai dalam kategori sedang, dan sebanyak 3 orang yang mendapatkan nilai dalam kategori rendah. Dari data tes maupun wawancara, dari data tersebut dapat diketahui bahwa kemampuan pemahaman konsep matematis sebagian besar siswa kelas X SMA Kristen Petra Malang dikatakan sudah baik.
\end{abstract}

Kata Kunci: Analisis Kemampuan Pemahaman Konsep, SPLDV

\section{PENDAHULUAN}

Menurut Utari (2012), pemahaman konsep matematika adalah mengerti benar tentang konsep matematika, yaitu siswa dapat menerjemahkan, menafsirkan, dan menyimpulkan suatu konsep matematika berdasarkan pembentukan pengetahuannya sendiri, bukan sekedar menghafal. Sebagai fasilitator dalam di dalam pembelajaran, guru semestinya memiliki pandangan bahwa materi-materi yang diajarkan kepada siswa bukan hanya sebagai hafalan. Namun, lebih dari itu yaitu memahami konsep yang diberikan. Dengan memahami, siswa dapat lebih mengerti akan konsep materi pelajaran itu sendiri, bukan hanya sekedar dihafal.

Pemahaman terhadap konsep-konsep matematika merupakan dasar untuk belajar matematika secara bermakna (Murizal, 2012). Namun, pada kenyataannya banyak siswa yang kesulitan dalam memahami konsep matematika. Bahkan, mereka kebanyakan tidak mampu mendefinisikan kembali bahan pelajaran matematika dengan bahasa mereka sendiri serta membedakan contoh dan bukan contoh dari sebuah konsep. Apalagi memaknai matematika dalam bentuk nyata.

Sedangkan Annajmi (2016: 2), mengemukakan bahwa siswa memiliki kemampuan pemahaman konsep matematika apabila siswa mampu menjelaskan konsep atau mampu mengungkapkan kembali apa yang telah dikomunikasikan kepadanya, menggunakan konsep pada berbagai situasi yang berbeda, dan mengembangkan beberapa akibat dari adanya suatu konsep. Hal ini membuktikan bahwa kemampuan pemahaman konsep penting diterapkan kepada siswa.

Kamarullah (2017) menegaskan siswa dituntut sesuai kurikulum dengan tujuan lebih komprehensif, yakni: (1) memahami konsep matematika, menjelaskan keterkaitan antar konsep serta mengaplikasikan algoritma atau konsep, secara akurat, luwes, efisien dan tepat dalam pemecahan masalah; (2) menggunakan penalaran pada sifat dan pola, melakukan manipulasi matematika dalam membuat generalisasi, menyusun bukti atau menjelaskan gagasan dan pernyataan matematika; (3) memecahkan permasalahan yang meliputi kemampuan memahami masalah, merancang model dalam matematika, menyelesaikan model dan menafsirkan solusi yang diperoleh; (4) mengkomunikasikan gagasan dengan simbol, tabel, diagram atau media lain untuk memperjelas keadaan atau permasalahan; (5) mempunyai sikap menghargai kegunaan 


\section{RAINSTEK \\ RAINSTEK (Jurnal Terapan Sains \& Teknologi)}

Fakultas Sains dan Teknologi Universitas Kanjuruhan Malang

matematika dalam kehidupan sehari-hari, seperti rasa ingin tahu, perhatian dan minat dalam mempelajari matematika, serta memiliki sikap ulet dan percaya diri dalam pemecahan masalah.

Penelitian sebelumnya dilakukan oleh Suraji, dkk (2018) sebagai penunjang tentang kemampuan pemahaman konsep matematis siswa dengan judul "Analisis Kemampuan Pemahaman Konsep Matematis dan Pemecahan Masalah Matematis Siswa SMP pada Materi Sistem Persamaan Linear Dua Variabel (SPLDV)". Berdasarkan hasil analisis kemampuan tersebut disimpulkan bahwa kemampuan pemahaman konsep matematis dan kemampuan pemecahan masalah matematis siswa SMP pada materi SPLDV masih rendah terutama dalam mengaplikasikan pada kehidupan sehari-hari.

Hasil penelitian yang dilakukan oleh Kartika (2018), dengan judul "Analisis Kemampuan Pemahaman Konsep Matematis Peserta didik Kelas VII SMP pada Materi Bentuk Aljabar", berdasarkan hasil tes, nilai rata-rata kemampuan pemahaman konsep matematis peserta didik yang bejumlah 30 orang, secara keseluruhan dikategorikan rendah. Hal yang mempengaruhi rendahnya kemampuan pemahaman konsep ini disebabkan karena peserta didik kurang mampu menjelaskan atau menuangkan kembali konsep yang mereka dapatkan dan menyajikan konsep dalam bentuk representasi matematis sehingga peserta didik kurang akan kemampuan pemahaman konsep.

Berdasarkan indikator pemahaman konsep dari berbagai sumber, indikator pemahaman konsep yang digunakan dalam penelitian ini adalah indikator pemahaman konsep menurut Wardhani (2008). Dari indikator tersebut, yang digunakan dalam penelitian ini hanya 5 poin dikarenakan keterbatasan waktu dan tenaga dari peneliti. Indikator yang digunakan tersebut adalah sebagai berikut:
a. Menyatakan ulang sebuah konsep;
b. Mengklasifikasikan objek menurut sifat tertentu sesuai konsepnya;
c. Memberi contoh dan bukan contoh dari suatu konsep;
d. Menggunakan dan memanfaatkan serta memilih prosedur atau operasi tertentu;
e. Mengaplikasikan konsep atau algoritma pada pemecahan masalah;

Dari paparan di atas, maka sangat diperlukan untuk dilakukan analisis kemampuan pemahaman konsep matematis siswa dalam mengerjakan soal sistem persamaan linear dua variabel (SPLDV).

\section{METODE PENELITIAN}

Jenis penelitian yang digunakan adalah penelitian kualitatif yang bertujuan untuk mengetahui secara langsung bagaimana kemampuan pemahaman konsep matematis siswa dalam menyelesaikan soal-soal SPLDV. Maka pendekatan penelitian ini adalah pendekatan kualitatif dengan menggunakan jenis penelitian deskriptif. Sumber data dalam penelitian ini adalah kelas X SMA Kristen Petra Malang yang berjumlah 25 peserta yang terdiri dari 7 siswa laki-laki dan 18 siswa perempuan, akan diambil 6 subjek sebagai subjek penelitian. Prosedur pengumpulan data menggunakan metode tes dan wawancara. Tes digunakan untuk mendapatkan data kemampuan pemahaman konsep yang dilakukan siswa dalam menyelesaikan soal-soal sistem persamaan linear dua variabel (SPLDV). Pada penelitian ini menggunakan wawancara semi terstruktur untuk memperkuat temuan data dari hasil tes. Wawancara dilakukan pada 6 subjek penelitian yang telah ditentukan masing-masing kelompok yaitu 2 subjek penelitian kelompok tinggi (nilai tinggi), 2 subjek penelitian kelompok sedang (nilai sedang), 2 subjek penelitian kelompok rendah (nilai rendah)

Teknik analisis data yang digunakan, yaitu reduksi data, penyajian data, dan penarikan kesimpulan. Reduksi data dilakukan dengan tiga tahap yaitu 1) mengoreksi hasil tes, 2) mengelompokan siswa kedalam 3 kelompok yaitu kelompok tinggi, kelompok sedang dan kelompok rendah, kemudian akan dipilih 6 subjek penelitian untuk menjadi subjek wawancara, 3) melakukan wawancara pada subjek yang telah dipilih. Penyajian data pada penelitian ini ada 


\section{RAIINSTEK \\ RAINSTEK (Jurnal Terapan Sains \& Teknologi)}

Fakultas Sains dan Teknologi Universitas Kanjuruhan Malang

3 yaitu 1) hasil pekerjaan siswa, 2) hasil wawancara dan 3) data analisis yang berupapemahaman konsep siswa dalam menyelesaikan soal sistem persamaan linear dua variabel (SPLDV).

Penarikan kesimpulan dapat dilakukan dengan mengkroscek hasil pekerjaan siswa dengan hasil wawancara sehingga dapat diketahui pemhaman konsep yang dimiliki siswa. Keabsahan temuan menggunakan triangulasi teknik yaitu pengumpulan data dengan bermacammacam cara pada sumber yang sama, pada penelitian ini menggunakan cara tes dan wawancara pada sumber yang sama dan triangulasi sumber adalah membandingkan antara hasil tes dan hasil wawncara, pada penelitian ini yang dibandingkan adalah hasil pekerjaan siswa dengan hasil wawancara siswa. Tahap-tahap penelitian ini yaitu perencanaan, pelaksanaan, dan analisis data.

\section{HASIL DAN PEMBAHASAN}

Hasil tes siswa dianalisis menggunakan pedoman rubrik penskoran pemahaman konsep matematika. Perolehan skor masing-masing item tes dijumlahkan untuk setiap siswa. Berdasarkan skor yang diperoleh, siswa dikelompokan menurut kelompok tinggi, sedang dan rendah.

\section{Tabel 1. Rubrik Penskoran Pemahaman Konsep Matematika}

\begin{tabular}{cl}
\hline Skor & \multicolumn{1}{c}{ Sajian Jawaban } \\
\hline 4 & $\begin{array}{l}\text { Konsep dan prinsip terhadap soal matematika secara lengkap, penggunaan istilah dan } \\
\text { notasi secara tepat, penggunaan algoritma secara lengkap dan benar }\end{array}$ \\
3 & $\begin{array}{l}\text { Konsep dan prinsip terhadap soal matematika hampir lengkap, penggunaan istilah dan } \\
\text { notasi matematika hampir benar, perhitungan secara umum benar namun mengandung } \\
\text { sedikit sedikit kesalahan } \\
\text { Konsep dan prinsip terhadap soal matematika kurang lengkap, jawaban mengandung } \\
\text { perhitungan yang salah }\end{array}$ \\
& $\begin{array}{l}\text { Konsep dan prinsip terhadap soal matematika sangat terbatas, jawaban sebagian besar } \\
\text { belum lengkap dan mengandung perhitungan yang salah } \\
\text { Tidak menunjukan pemahaman konsep dan prinsip terhadap soal matematika }\end{array}$ \\
\hline
\end{tabular}

Berdasarkan hasil tes pemahaman konsep matematis siswa, maka diperoleh data seperti yang tersaji pada tabel berikut.

Tabel 2. Hasil Tes Pemahaman Konsep Matematis

\begin{tabular}{lll}
\hline Kode Subjek & Skor & Kategori \\
\hline $\mathrm{A}_{1}$ & 100 & Tinggi \\
$\mathrm{A}_{2}$ & 75 & Sedang \\
$\mathrm{A}_{3}$ & 91,6 & Tinggi \\
$\mathrm{A}_{4}$ & 91,6 & Tinggi \\
$\mathrm{A}_{5}$ & 25 & Rendah \\
$\mathrm{A}_{6}$ & 75 & Sedang \\
$\mathrm{A}_{7}$ & 91,6 & Tinggi \\
$\mathrm{A}_{8}$ & 33,3 & Rendah \\
$\mathrm{A}_{9}$ & 75 & Sedang \\
$\mathrm{A}_{10}$ & 66,6 & Sedang \\
$\mathrm{A}_{11}$ & 33,3 & Rendah \\
$\mathrm{A}_{12}$ & 91,6 & Tinggi \\
$\mathrm{A}_{13}$ & 75 & Sedang \\
$\mathrm{A}_{14}$ & 91,6 & Tinggi \\
\hline
\end{tabular}




\section{RAIINSTEK \\ RAINSTEK (Jurnal Terapan Sains \& Teknologi)}

Fakultas Sains dan Teknologi Universitas Kanjuruhan Malang

Vol. 1, No.4, 2019

\begin{tabular}{lll}
\hline $\mathrm{A}_{15}$ & 91,6 & Tinggi \\
$\mathrm{A}_{16}$ & 91,6 & Tinggi \\
$\mathrm{A}_{17}$ & 91,6 & Tinggi \\
$\mathrm{A}_{18}$ & 83,3 & Tinggi \\
$\mathrm{A}_{19}$ & 91,6 & Tinggi \\
$\mathrm{A}_{20}$ & 75 & Sedang \\
$\mathrm{A}_{21}$ & 91,6 & Tinggi \\
$\mathrm{A}_{22}$ & 91,6 & Tinggi \\
$\mathrm{A}_{23}$ & 75 & Sedang \\
$\mathrm{A}_{24}$ & 75 & Sedang \\
$\mathrm{A}_{25}$ & 91,6 & Tinggi \\
\hline
\end{tabular}

Jawaban siswa dikoreksi kemudian dikelompokan menjadi 3 kelompok yaitu kelompok tinggi (nilai tinggi), kelompok sedang (nilai sedang), dan kelompok rendah (nilai rendah). Setelah itu subjek penelitian diambil sebanyak 6 siswa dipilih masing-masing 2 subjek dari setiap kelompok.

Tabel 3. Pengelompokan Hasil Tes Tertulis

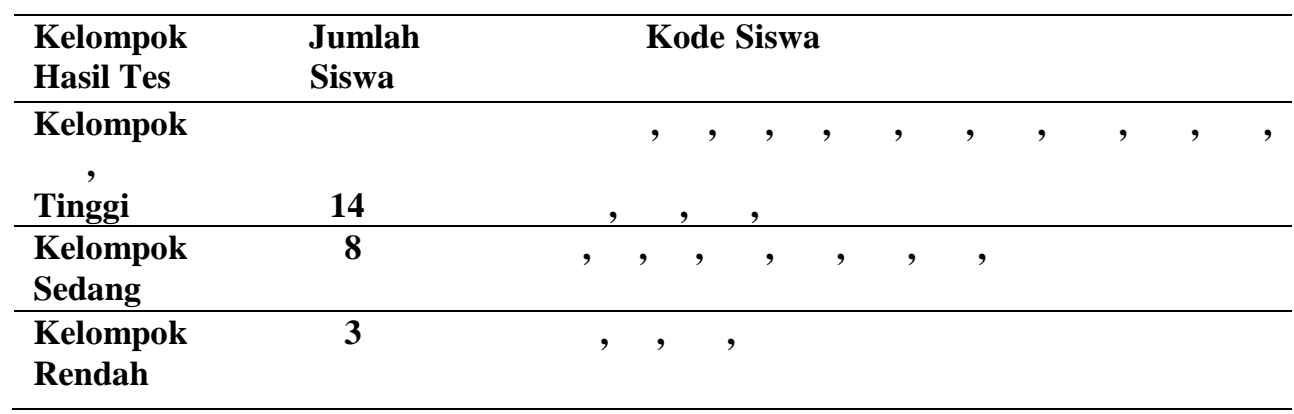

Dari 25 siswa yang mengikuti tes kemampuan pemahamaman konsep matematis, hanya 6 siswa yang dipilih sebagai subjek penelitian, dan dipilih masing-masing 2 subjek dari tiap kategori tinggi, rendah dan sedang. Daftar subjek penelitian tersaji pada tabel berikut.

Tabel 4. Daftar Subjek Penelitian

\begin{tabular}{|c|c|}
\hline $\begin{array}{ll}\text { No } & \text { Kode Siswa }\end{array}$ & Kelompok \\
\hline 1 & Tinggi \\
\hline 2 & Tinggi \\
\hline 3 & Sedang \\
\hline 4 & Sedang \\
\hline 5 & Rendah \\
\hline 6 & Rendah \\
\hline
\end{tabular}

Pedoman wawancara tes pemahaman konsep digunakan untuk memperoleh keterangan mengenai pemahaman konsep siswa dalam menyelesaikan soal SPLDV dengan cara tanya jawab sambil bertatap muika, seperti yang tersaji pada tabel berikut. 


\section{RAINSTEK \\ RAINSTEK (Jurnal Terapan Sains \& Teknologi)}

Fakultas Sains dan Teknologi Universitas Kanjuruhan Malang

Tabel 5. Pedoman Wawancara Tes Pemahaman Konsep

\begin{tabular}{|c|c|c|}
\hline No & Indikator Pemahaman Konsep & Wawancara \\
\hline 1. & Menyatakan ulang sebuah konsep & $\begin{array}{l}\text { a. Apa yang kamu pahami dari soal } \\
\text { tersebut? } \\
\text { b. Coba dijelaskan lagi apa itu SPLDV? }\end{array}$ \\
\hline 2. & $\begin{array}{l}\text { Mengklasifikasikan objek-objek } \\
\text { menurut sifat-sifat tertentu (sesuai } \\
\text { dengan konsepnya) }\end{array}$ & $\begin{array}{l}\text { a. Dari soal tersebut solusi apa yang tepat } \\
\text { untuk menjawab soal tersebut serta alasan! } \\
\text { b. Bagaimana kamu menjawab soal tersebut } \\
\text { dengan solusi yang kamu pilih! }\end{array}$ \\
\hline 3. & $\begin{array}{l}\text { Memberi contoh dan bukan contoh } \\
\text { dari konsep }\end{array}$ & $\begin{array}{l}\text { a. Coba tuliskan kembali contoh dari SPLDV! } \\
\text { b. Bagaimana langkah yang kamu gunakan } \\
\text { untuk menyelesaikan soal tersebut! }\end{array}$ \\
\hline 4. & $\begin{array}{l}\text { Menggunakan, memanfaatkan dan } \\
\text { memilih prosedur atau operasi } \\
\text { tertentu }\end{array}$ & $\begin{array}{l}\text { a. Jelaskan bagaimana kamu menyelesaikan } \\
\text { soal tersebut! } \\
\text { b. mengapa kamu menggunakan cara tersebut? } \\
\text { c. Di bagian manakah kamu menemukan } \\
\text { kesulitan? }\end{array}$ \\
\hline 5. & $\begin{array}{l}\text { Mengaplikasikan konsep atau } \\
\text { algoritma pada pemecahan masalah }\end{array}$ & $\begin{array}{l}\text { a. Apa yang kamu ketahui dari soal tersebut? } \\
\text { b. Coba selesaikan soal tersebut dengan } \\
\text { strategi yang kamu gunakan! }\end{array}$ \\
\hline
\end{tabular}

Secara garis besar kesimpulan dari hasil tes kemampuan pemahaman konsep matematis siswa dari 6 subjek yang dipilih, maka diperoleh data seperti yang tersaji pada tabel berikut.

Tabel 6. Analisis Hasil Tes Kemampuan Pemahaman Konsep

\begin{tabular}{|c|c|c|}
\hline Subjek & $\begin{array}{l}\text { No } \\
\text { Soal }\end{array}$ & Kesimpulan \\
\hline \multirow{3}{*}{$\mathrm{A}_{1}$} & 1 & $\begin{array}{l}\text { Subjek dapat mengerjakan soal dan tidak melakukan kesalahan } \\
\text { apapun }\end{array}$ \\
\hline & 2 & $\begin{array}{l}\text { Subjek dapat menyelesaikan soal dengan tidak melakukan kesalahan } \\
\text { apapun }\end{array}$ \\
\hline & 3 & $\begin{array}{l}\text { Subjek dapat menyelesaikan soal dengan benar tidak melakukan } \\
\text { kesalahan apapun }\end{array}$ \\
\hline \multirow{3}{*}{$\mathrm{A}_{21}$} & 1 & $\begin{array}{l}\text { Subjek mengerjakan soal kurang tepat, yang diminta dari soal dengan } \\
\text { cara substitusi, tetapi subjek mengerjakan dengan metode campuran }\end{array}$ \\
\hline & 2 & Subjek mampu mengerjakan soal dengan lengkap dan benar \\
\hline & 3 & $\begin{array}{l}\text { Subjek dapat mengerjakan soal dengan benar tanpa melakukan } \\
\text { kesalahan apapun }\end{array}$ \\
\hline \multirow[t]{3}{*}{$\mathrm{A}_{24}$} & 1 & $\begin{array}{l}\text { Subjek tidak bisa mengerjakan soal, yang diminta dengan cara } \\
\text { substitusi tetapi subjek menyelesaikan dalam metode eliminasi, } \\
\text { sehingga tidak bisa menemukan jawaban }\end{array}$ \\
\hline & 2 & Subjek mampu mengerjakan soal dengan benar \\
\hline & 3 & Subjek dapat menyelesaikan soal dan tidak melakukan kesalahan \\
\hline \multirow{4}{*}{$\mathrm{A}_{2}$} & 1 & Subjek tidak bisa menjawab soal dengan benar \\
\hline & 2 & $\begin{array}{l}\text { Subjek mampu mengerjakan soal dengan benar tanpa melakukan } \\
\text { keslahan }\end{array}$ \\
\hline & 3 & Subjek dapat mengerjakan soal dengan lengkap dan benar \\
\hline & 1 & Subjek tidak bisa menjawab soal dengan benar, dan subjek masih \\
\hline
\end{tabular}




\section{RAIINSTEK \\ RAINSTEK (Jurnal Terapan Sains \& Teknologi)}

Fakultas Sains dan Teknologi Universitas Kanjuruhan Malang

\begin{tabular}{lll}
\hline & \multicolumn{3}{c}{ belum mampu memahami soal tes yang diberikan dengan benar } \\
\cline { 2 - 3 } & 2 & Subjek belum bisa mengerjakan soal dengan lengkap dan benar \\
\cline { 2 - 3 } & 3 & $\begin{array}{l}\text { Subjek tidak bisa mengerjakan soal yang diberikan, dan subjek tidak } \\
\text { menuliskan sama sekali jawaban pada lembar jawaban }\end{array}$ \\
\hline & 1 & $\begin{array}{l}\text { Subjek mencoba mengerjakan soal akan tetapi proses pengerjaannya } \\
\text { salah }\end{array}$ \\
\cline { 2 - 3 } $\mathrm{A}_{8}$ & $\begin{array}{l}\text { Subjek tidak bisa menjawab soal tes dengan lengkap dan benar } \\
\end{array}$ & Subjek tidak dapat mengerjakan soal yang diberikan \\
\hline
\end{tabular}

Pemahaman konsep matematika dapat dilihat dari beberapa indikator, yaitu 1) menyatakan ulang sebuah konsep, 2) mengklasifikasikan objek-objek menurut sifat-sifat tertentu (sesuai dengan konsepnya), 3) memberi contoh dan bukan contoh dari konsep, 4) menggunakan, memanfaatkan dan memilih prosedur atau operasi tertentu, 5) mengaplikasikan konsep atau algoritma pada pemecahan masalah. Berikut adalah pembahasan setiap indikator yang digunakan. Berikut pembahasan kesalahan siswa dalam menyelesaikan soal sistem persamaan linear dua variabel (SPLDV) kelas XSMA Kristen Petra Malang.

Kesalahan dalam menyatakan ulang sebuah konsep, berdasarkan hasil analisis jawaban siswa, sebagian besar siswa dapat mendefinisikan sistem persamaan linear dua variabel (SPLDV) tesebut walaupun penggunaan bahasanya masih kurang tepat. Kesalahan siswa dalam indikaor ini adalah kesalahan dalam menuliskan definisi dari suatu konsep.

Kesalahan dalam mengklasifikasikan objek-objek menurut sifat-sifat tertentu (sesuai dengan konsepnya), berdasarkan hasil analisis jawaban siswa, kesalahan siswa dalam indikator ini hanya ada sedikit kekeliruan dalam mengggunakan metode atau cara yang digunakan sesuai dengan konsep pada materi sistem persamaan linear dua variabel (SPLDV).

Kesalahan yang dilakukan oleh subjek $\mathrm{A}_{21}$ untuk soal nomor 1 adalah salah menggunakan metode yang diminta dari soal tes sehingga hasil akhirnya juga salah. Seperti pada gambar di bawah ini.

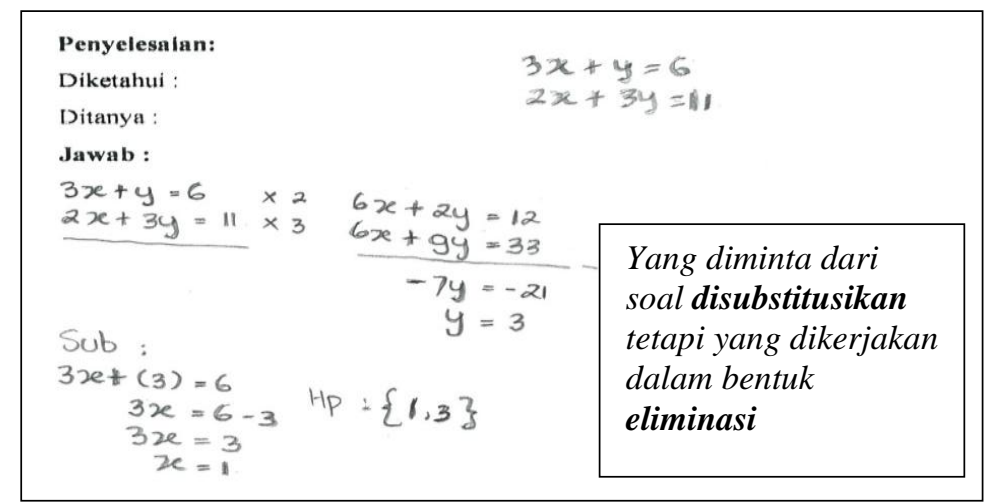

\section{Gambar 1. Hasil Pekerjaan $\mathbf{A}_{21}$ Soal Nomor 1}

Kesalahan dalam memberi contoh dan bukan contoh, berdasarkan hasil analisis jawaban siswa, sebagian besar kesalahan siswa pada indikator ini adalah kesalahan dalam menyebutkan contoh dan bukan contoh dari konsep.

Kesalahan dalam menggunakan, memanfaatkan dan memilih prosedur atau operasi tertentu, berdasarkan hasil analisis jawaban siswa, sebagian besar kesalahan dalam indikator ini adalah kesalahan dalam mengoperasikan soal. 


\section{RAIINSTEK \\ RAINSTEK (Jurnal Terapan Sains \& Teknologi)}

Fakultas Sains dan Teknologi Universitas Kanjuruhan Malang

Kesalahan subjek $\mathrm{A}_{5}$ dalam mengerjakan soal nomor 2 adalah subjek tidak bisa menjawab soal dengan lengkap dan benar, subjek hanya mampu membuat model matematika dan mengeliminasikan tetapi tidak bisa mensubstitusikan sehingga hasil akhirnya salah.

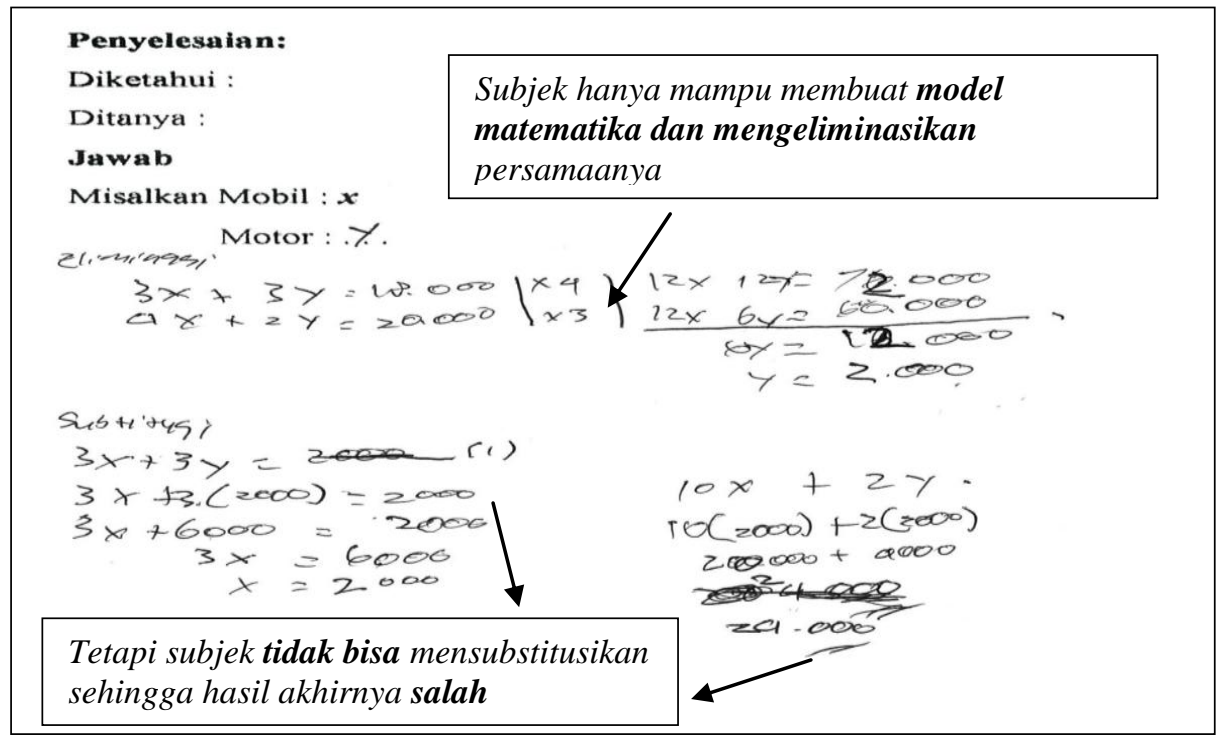

Gambar 2. Hasil Pekerjaan $\mathbf{A}_{5}$ Soal Nomor 2

Kesalahan dalam mengaplikasikan konsep atau algoritma pada pemecahan masalah, berdasarkan hasil analisis jawaban siswa, sebagian besar kesalahan siswa dalam indikator ini adalah salah dalam mengaplikasikan konsep sehingga banyak subjek yang tidak menuliskan jawaban sampai hasil akhir bahkan tidak menuliskan jawaban sama sekali.

Kesalahan subjek $A_{5}$ dalam menyelesaikan soal nomor 3 adalah subjek tidak mampu mengerjakan soal tes. subjek tidak menuliskan sama sekali jawaban dilembar jawaban yang telah disediakan.

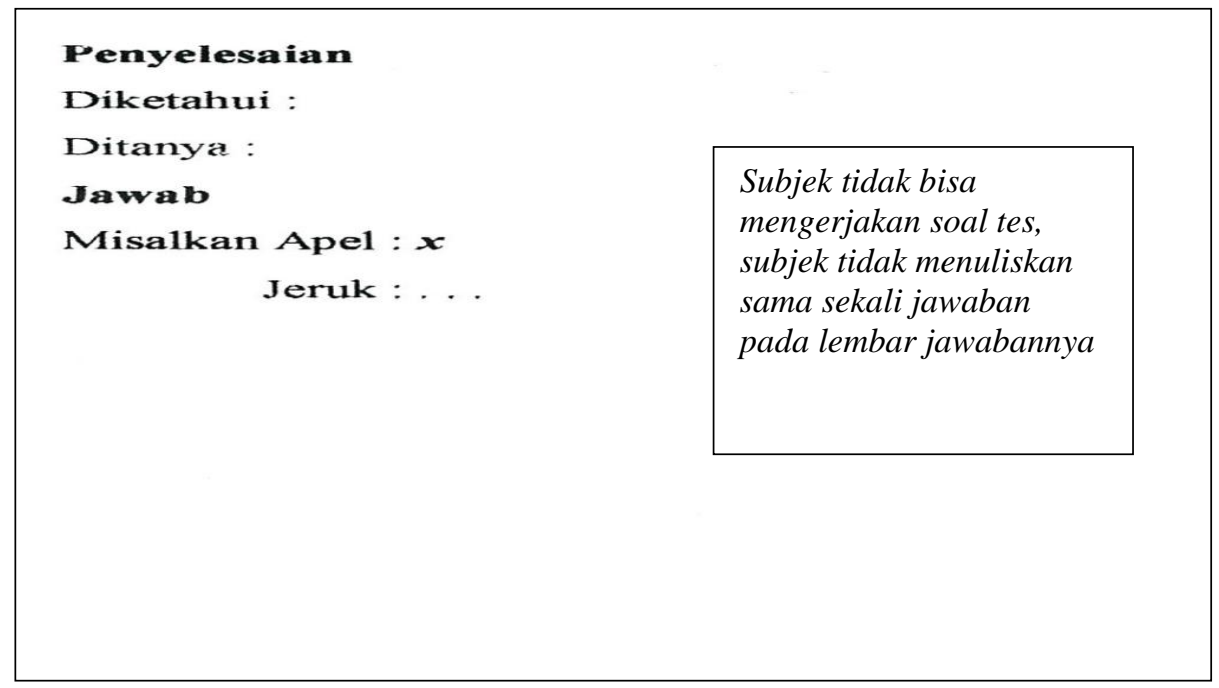

Gambar 3. Hasil Pekerjaan $A_{5}$ Soal Nomor 3 


\section{RAIINSTEK \\ RAINSTEK (Jurnal Terapan Sains \& Teknologi)}

Fakultas Sains dan Teknologi Universitas Kanjuruhan Malang

\section{PENUTUP}

Berdasarkan penelitian analisis kemampuan pemahaman konsep siswa dalam menyelesaikan soal SPLDV, beberapa kesimpulan dari penelitian ini antara lain:

1. Hasil analisis kemampuan pemahaman konsep siswa berdasarkan 6 subyek penelitian menunjukan bahwa dengan kategori rendah dapat mengerjakan soal yang diberikan walaupun hanya menuliskan sedikit jawaban dan jawaban akhirnya juga salah. Siswa dengan kategori sedang mampu menyelesaikan soal dengan langkah-langkah yang benar tetapi kurang lengkap, sehingga tidak mendapatkan hasil yang benar. Sedangkan siswa dengan kategori tinggi mampu menyelesaikan soal yang diberikan dengan benar.

2. Siswa dengan kemampuan pemahaman konsep tinggi sebanyak 14 dari 25 siswa. Siswa mampu mengerjakan soal tes pemahaman konsep yang diberikan dengan benar. Hal ini ditunjukan dari mampu memilih metode yang tepat untuk menjawab soal, mampu membuat model matematika dengan benar dan bisa menyelesaikan soal sampai pada penulisan jawaban akhir dengan lengkap dan benar.

3. Siswa dengan kemampuan pemahaman konsep sedang sebanyak 8 dari 25 siswa. Siswa mampu mengerjakan soal tes pemahaman konsep yang diberikan walaupun masih ada kekeliruan sedikit saat menjawab soal tes. Siswa mampu membuat model matematika dengan benar dan bisa menyelesaikan soal dengan benar akan tetapi subyek belum mampu memilih metode yang tepat saat menjawab soal tes.

4. Siswa dengan keampuan pemahaman konsep rendah sebanyak 3 dari 25 siswa. Siswa hanya mampu menuliskan sedikit jawaban namun salah. Subyek belum mampu memilih metode yang tepat untuk menjawab soal tes, belum mampu membuat model matematika, dan subyek tidak mampu menuliskan jawaban dengan benar.

Saran peneliti kaitannya dengan hasil penelitian ini antara lain guru diharapkan untuk lebih menekankan konsep kepada siswa agar siswa lebih mudah dalam mengerjakan soal selain itu bagi peneliti selanjutnya, untuk meminimalkan dan menghindari kesalahan yang umumnya dilakukan oleh siswa dalam menyelesaikan soal tes sistem persamaan linear dua variabel (SPLDV) adalah memberikan penguatan tentang proses mensubstitusikan dan mengeliminasikan dari suatu persamaan serta cara mengaplikasikan soal ke dalam model matematika. Agar dalam proses keterampilan mengerjakan soal lebih mudah dipahami oleh siswa.

\section{DAFTAR PUSTAKA}

Annajmi. (2016). Peningkatan Kemampuan Pemahaman Konsep Matematik Siswa SMP melalui penemuan terbimbing berbantu software geogebra. MES (Journal of Mathematics Education and Science), 2 (1): 1-9.

Kamarullah. (2017). Pendidikan Matematika di Sekolah Kita. Jurnal Al Khawarizmi, 1 (1): 2132.

Kartika, Yuni. (2018). Analisis Kemampuan Pemahaman Konsep Matematis Peserta Didik Kelas VII SMP pada Materi Bentuk Aljabar. Jurnal Pendidikan Tambusai. 2 (4): 777785 .

Murizal, Angga. (2012). Pemahaman Konsep Matematis dan Model Pembelajaran Quantum Teaching. Jurnal Pendidikan Matematika 1 (1): 19-23.

Sahriah, dkk. (2012). "Analisis Kesalahan Siswa dalam Menyelesaikan Soal Matematika Materi Operasi Pecahan Bentuk Aljabar Kelas VIII SMP Negeri 2 Malang”. Jurnal Universitas Negeri Malang 1(1):2.

Suraji, Maimunah dan Sehatta Saragih. (2018). Analisis Kemampuan Pemahaman Konsep Matematis dan Kemampuan Pemecahan Masalah Matematis Siswa SMP pada Materi Sistem Persamaan Linear Dua Variabel (SPLDV). Suska Journal of Mathematics Education. 4(1): 9-16. 


\section{RAÎNSTEK \\ RAINSTEK (Jurnal Terapan Sains \& Teknologi)}

Fakultas Sains dan Teknologi Universitas Kanjuruhan Malang

Utari, Vivi. (2012). Peningkatan Kemampuan Pemahaman Konsep Melalui Pendekatan PMR Dalam Pokok Bahasan Prisma dan Limas. Jurnal Pendidikan Matematika 1 (1): 33-38. Tersedia di: http://ejiournal.unp.ac.id/students/index.php/pmat/article/view/1159/851 [diakses 13-06-2017].

Wardhani, Sri . (2008). Pengembangan Keterampilan Proses Sains dalam Pembelajaran Kromatografi Lapis Tipis Melalui Praktikum Skala Mikro. Jurnal Inovasi Pendidikan Kimia. Vol 2, No 2, Hal: 317-322. 